\title{
Australia's Counter-Terrorism Policies Since September 11, 2001: Harmonising National Security, Independent Oversight and Individual Liberties
}

\author{
Ashutosh Misra \\ Abstract: Australia has remained insulated from mega terrorist attacks, but post- \\ September 11 its involvement in the war on terror in Afghanistan, Iraq and \\ against the Islamic State in Iraq and Syria (ISIS) has brought terrorism into its \\ backyard. In the wake of these emerging threats, particularly home-grown \\ terrorism (HGT), successive governments have introduced changes in the \\ counter-terrorism (CT) laws, and expanded the Criminal Code Act 1995 \\ (Commonwealth-Cth) at the recommendations of the Council of Australian \\ Governments (COAG). Former prime minister Tony Abbott and his successor \\ Malcolm Turnbull have introduced a series of significant policy measures to \\ curb terrorism in and from Australia. These measures have also stirred up a \\ debate among experts and civil society members, who consider them as being \\ detrimental to civil liberties. The article undertakes a critical review of the \\ evolution of CT laws and measures in Australia since September 11, to \\ understand the criticism of the legislative changes, and to what extent has \\ Australia succeeded in harmonising national security and individual liberties \\ with an effective oversight mechanism.
}

\section{Objectives}

Australia has, so far, escaped any major terrorist attack on its soil, but has nonetheless been affected by terrorism. The September 11 attacks in the US and Australia's subsequent involvement in the war on terror in Afghanistan, Iraq and 
more recently against the Islamic State in Iraq and Syria (ISIS), have made it the prime target of terrorist groups. Increased terrorist threats have triggered a policy churn at the commonwealth, state and territory level, prompting a number of reviews for amending Australia's counter-terrorism (CT) laws, to cope with the rapidly transform- ing nature of terrorism at home. These amendments have also attracted a fair share of criticism from experts. In this context, this article has four broad objectives. First, it presents a brief overview of terrorism in Australia to contextualise Australia's current CT policies. Second, it captures the transformation in the nature of terrorist threats in Australia in recent years. Third, the article examines the recent legislative amend- ments and other initiatives introduced under Tony Abbott and Malcolm Turnbull. And fourth, it discusses some of the criticism triggered in the wake of these new terrorism laws and CT measures.

\section{Australia's Experience with Terrorism: An Overview}

Australia witnessed its first act of terrorism in 1915, when two camel-drivers attacked a commuter train in New South Wales to protest against the shutting down of their illegal meat business, and to express their solidarity with Turkey during the First World War, by targeting a British ally. ${ }^{1}$ Sixty years later in 1972 the Yugoslav General Trade Agency in Sydney was bombed by anti-Semitic groups. Historians argue that Australian CT mechanisms were shaped by the bureaucratic deliberations that followed the 1972 Munich Olympics massacre, carried out by the Palestinian Black September group, in which 11 Israeli 
athletes were killed. ${ }^{2}$ In September 1977, a member of the Ananda Marga ${ }^{3}$ religious group kidnapped the Indian defence attaché Colonel Iqbal Singh and his wife Darshan Kaur Singh in Canberra to avenge the arrest of their leader Prabhat Rajan Sarkar by the Indian government. ${ }^{4}$ In 1978, one Ananda Margi was also charged with planting gelignite sticks in a bin near the Indian prime minister Morarji Desai's hotel in Sydney, during the Commonwealth Summit. In 1980, the Turkish Consul General along with his bodyguard was assassinated in Sydney, and two years later the Israeli Consulate at the Hakoah Club in Sydney was bombed, followed by the bombing of Turkish Consulate in Melbourne in $1986 .{ }^{5}$ PostSeptember 11, in reaction to Australia's military involvement in Afghanistan and Iraq, Australians became the targets of terrorist groups overseas. Most notably, 88 Australians were killed on October 12, 2002, in the Bali bombings. Three years later, another attack in October 2005 in Bali killed four Australians. The attack spurred the Australian Parliament to move swiftly to enact a raft of new offences prohibiting 'harming Australian citizens or residents abroad'. ${ }^{6}$ The Australian defence forces deployment in Afghanistan has already resulted in 40 soldiers being killed and another 261 injured. $^{7}$ Overall, 100 Australians have been killed in terrorist strikes overseas, but now threats have emerged from within as well. A number of home-grown terrorist (HGT) plots have been foiled in recent years, leading to the prosecution of 35 people and the conviction of another 26. Forty passports were cancelled or denied for security reasons until $2010^{8}$ and another 60 suspects lost their passports in 2014, to prevent them from travelling overseas to join ISIS. $^{9}$ 


\section{Home-Grown Terrorism}

Post-September 11, the major domestic threat to Australia has emanated from Australians linked with the al-Shabaab and al-Qaeda who were displeased with Australia's involvement in Iraq and Afghanistan. ${ }^{10}$ With the growing numbers of Australian Muslims of Middle Eastern and South Asian origin, resentment over Australia's involvement in Iraq and Afghanistan is understandable. ${ }^{11}$ In 2003-2004, Faheem Lodhi, an Australian, was charged with plotting bombings on the national electricity grid and at some defence locations. In 2005, in Operation Pendennis, nine Australians were arrested for plotting bombings in Sydney, and 13 were arrested in Melbourne for plotting mass casualties, to compel an Australian withdrawal from Iraq. In 2009, Operation Neath led to the arrest of five Somali and Lebanese operatives, associated with al-Shabaab group and charged with plotting an attack on the Holsworthy army barracks in Sydney. In 2010, in coordinated raids in Melbourne, Sydney and Perth, police arrested Kurdistan Workers Party (PKK) sympathisers. In 2012, in Operation Astley, a joint Australian and Federal Police-Victorian Police force raided the Al Furqan Centre in Melbourne and seized computers and firearms meant for terrorist plots. $^{12}$

\section{Leaderless Jihadis in Australia}

Australia has also witnessed a number of attacks (described by experts as 
'leaderless resistance') perpetrated by self-radicalised individuals ('leaderless jihadis'), some of whom were delinked from any larger movement or network support. ${ }^{13}$ Categorised as 'fifth generation warfare', experts say that leaderless resistance is triggered by several political, social and technological trends, wherein new technology, particularly the Internet, functions as a force multiplier for operatives. ${ }^{14}$ Marc Sageman argues that increased border scrutiny and stringent immigration procedures breed home-grown jihadis, as a part of the third wave of terrorism; the first and second Afghan jihad being the first and second wave, respectively. ${ }^{15}$ Australia is experiencing home-grown attacks and Islamic radicalisation under the third wave.

Former prime minister Tony Abbott revealed that the "number of foreign fighters, known sympathisers, supporters of extremism and potential home-grown terrorists impli- cated in serious investigations had increased'. ${ }^{16}$ He said that ' 110 Australians had travelled overseas to Iraq and Syria and 20 of them have been killed so far' and 'the number of Australians with hands-on-experience' had grown manifold. These had been 'trained in Afghanistan and Pakistan', and 'two-thirds' of these had returned to Australia. ${ }^{17}$ At one stage the Australian Security Intelligence Organisation (ASIO) was handling over '400 high-priority CT investigations', registering a twofold increase between 2013 and 2014. ${ }^{18}$ Describing the rapidly changing face of terrorism in Australia, he said:

Today's terrorism requires little more than a camera-phone, a knife and a victim. These lone actor attacks are not new, but they pose a unique set of problems. All too often, alienated and unhappy people brood quietly. Feeling persecuted and looking for 
meaning, they self- radicalise online. They plan attacks which require little preparation, training or capability. The short lead time from the moment they decide they are going to strike, and then actually undertake the attack made it hard to disrupt their

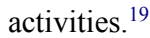

On the heels of the G20 summit in Brisbane in November 2014, Australian law enforcement agencies also carried out raids across Australia to round up suspects linked with extremist groups in the Middle East. Prior to the summit, in September 2014 the National Terrorist Public Alert level was raised by the former ASIO Chief, David Irvine, from 'medium' to 'high', suggesting that a terrorist attack was likely. ${ }^{20}$ In 2013-2014, ASIO had also issued 99 adverse assessments recommending that the government cancel passports on security grounds to prevent people, lured by the conflicts in Iraq and Syria, from leaving Australia. Based on a 12-month-long intense investigation, the largest terrorist raid in Australian history, Operation Appleby, was launched in in Melbourne and Sydney in September 2014, with 800 police officers from the Australian Federal Police (AFP), New South Wales Police and the ASIO, to bust a cell which was planning the beheading of a random person from the public, on camera while draped in a ISIS flag. ${ }^{21}$ In Sydney, 15 people were detained in connec- tion with the plot. These included Omarjan Azeri along with Mohammad Baryalei, the most senior Australian in ISIS ranks. Simultaneously, 180 heavily armed CT officers of the Queensland Police Service conducted raids and made arrests. ${ }^{22}$ In Melbourne, the 18-year-old Abdul Numan Haider was shot dead when he attacked two Joint-Anti- Terrorism Taskforce officers 
with a knife. ${ }^{23}$ In December 2014, another incident that shocked Australia saw an Iranian migrant, Man Haroon Monis, hold 18 people hostage in the Lindt Café in Martin Square, Sydney, for over 17 hours, resulting in the death of two hostages, along with Monis, in a pre-dawn police blitzkrieg. ${ }^{24}$

Attorney-General George Brandis has revealed that 71 Australians have left to fight in Syria and 73 passports have been cancelled, but the flow has remained 'pretty steady'. ${ }^{25} \mathrm{CT}$ units deployed at several airports have reportedly assessed 16,000 passengers, interviewed 1,600 of them and offloaded about 50, on security grounds. Officials also revealed that over 20 fighters have returned to Australia, potentially as highly radicalised individuals equipped with weapons and combat training. ${ }^{26}$ The list of Australians fighting for ISIS and reportedly killed included Yusef Ali, Amira Ali 'Karroum', Mohammad Ali Barylei, Housam Abdul Razzak, Roger Abbas, Ahmad Moussalli, Caner Temei, Abu Asma al Australi, Yusuf Toprakkaya, Sammy Salma, Abu Nour al Iraq, Adam Dahman, Mustapha Al Majzoub and Zakarayah Raad. Sydney teenager Jake Billardi, a.k.a. Abu Abdullah al-Australi, was killed in a suicide bombing. ${ }^{27}$ Another Sydney teenager, Abdullah Elimir, had become the poster boy of ISIS before being killed. ${ }^{28}$ In March 2015, two boys aged 16 and 17 were intercepted at the Sydney airport, and prevented from leaving Australia to join ISIS. ${ }^{29}$

According to the Australian foreign minister Julie Bishop, up to 40 Australian women had joined terrorist ranks in Syria, Iraq and Australia, and were labelled as 'jihadi brides'. These 'young females were used as sex slaves; some joined their partners or married fighters', despite the 'depraved ISIS 
terrorists' reputation for sexual slavery and brutal atrocities against women'. According to the foreign minister, one-fifth of all foreign fighters were women, of whom around 500 were from western countries. ${ }^{30}$ The ASIO Chief Duncan Lewis also confirmed that $30-40$ women had left Australia to be 'jihadi brides'. Lured by the attraction of jihad and the fanciful narratives woven around it, women from western countries fled to the Middle East through Facebook or Ask.fm which served as an online matchmaking site. Psychologists reason that an emotional attachment to heroes and macho types and perhaps a covert appreciation of violence, which they expressed through someone else, had attracted these women to the ISIS. ${ }^{31}$

In August 2014, in the wake of emerging threats from returning fighters and the increasing numbers of 'lone-wolf' attacks and HGT plots, the National Security Committee of Cabinet (NSC) expressed the need for the Department of the Prime Minister and the Cabinet to undertake a review of Australia's CT machinery to make it more effective for responding to emerging threats. On the issue of the return of fighters (approximately 230 individuals in Syria, Iraq and the Middle East, of whom around 20 have returned so far) the review proposed that the return be processed as per the advice of the Attorney General's department, for 'prosecution, revocation of citizenship, temporary or permanent exclusion from Australia, mandatory de-radica- lisation, cooperation with law enforcement and intelligence agencies and rehabilita- tion support'. ${ }^{\prime} 2$ 
A 2014 report of the Australian Transaction Reports and Analysis Centre (AUSTRAC) revealed that terrorism financing posed a major threat to Australian national security, the financial system, commercial organisations and non-profit orga- nisations. It funded terrorist activities, and established and sustained linkages between Australia-based terrorist groups and overseas networks. The report said that it funded the daily expenses of the operatives, including travel, training, propaganda and administrative expenses, as well as compensation for the wounded and the families of those killed. Modes of funding remained varied, ranging from self-funding or self- 
raised legitimate funds for supporting overseas activities or lone actors at home, to cross-border movement of cash or through the banking and remittance sectors, online payments, credit cards and through charities. ${ }^{33}$ In fact, the 2014 CT raids were triggered by reports of money transfers by a Sydney-based firm, Bistoel Reih Pty Ltd., run by Damour Sharrof and her husband Ahmad Alwash. Damour is the sister of Khaled Sharrouf (the most senior Australian in the ISIS ranks and infamous for posting a picture on social media of his seven-year-old son holding the severed head of a Syrian soldier). According to AUSTRAC, the firm was suspected of transferring $\$ 21.3$ million $^{34}$ between January and August 2014, to Turkey and Lebanon, of which \$9 million were unaccounted for and without any credible proof of receipt. ${ }^{35}$ The firm has been shut down following the raids. Authorities have also charged Omarjan Azari and his accomplice, already facing terrorism charges, for the transfer to $\$ 15,000$ to Iraq and Syria in August 2014. ${ }^{36}$ In October 2014, the United States Federal Bureau of Investigation had tipped off and helped the Australian authorities track down the 23-year-old Melbourne-based pizza shop employee Hassan El Sabasabi, who was later charged with six counts of terrorism financing to enable American citizens to join the ISIS and the al-Qaeda affiliated Jabahat al- Nusra. Former prime minister Tony Abbott cautioned that an estimated 100 financiers of overseas terrorism were living in Australia and were 'complicit' in terrorismrelated activities. ${ }^{37}$

\section{Post-September 11 Counter-Terrorism Measures}


Australia's key anti-terrorism laws are enshrined in Division 100 of the Criminal Code Act 1995 (Cth) which has been amended several times. Sections 100 to 105 deal with: definition of terrorism; receiving and providing training; ${ }^{38}$ possession and knowledge of terrorism materials, ${ }^{39}$ collection or making of documents; ${ }^{40}$ preparation of an act (even when not occurring); directing activities; ${ }^{41}$ membership of a terrorist organisation; ${ }^{42}$ recruitment; ${ }^{43}$ funding; ${ }^{44}$ association; ${ }^{45}$ terrorism financing $;{ }^{46}$ control orders; $;{ }^{47}$ and preventive detention orders. ${ }^{48}$ It lays down that children under the age of 16 cannot be detained and those under 18 would have to be detained separately from adults and can be visited by parents and guardians during detention. ${ }^{49}$

Following the September 11 attacks, the Council of Australian Governments (COAG) passed the CT framework which introduced changes in Part 5.3 (Terrorism) of the Criminal Code Act 1995 (Cth) and empowered the states and territories, 'To take whatever action is necessary to ensure that terrorists can be prosecuted'. ${ }^{50}$ In 2003, the states introduced legislation to empower the Commonwealth in matters of terrorism and the Criminal Code Amendment (Terrorism) Act 2003 was passed. To facilitate consultation between the states, territories and the commonwealth, an Intergovernmental Agreement on Counterterrorism Laws was signed on June 25, 2004. In 2005, following the London bombings, the Anti-Terrorism Act (No.1) (No. 2) (Cth) was passed to strengthen CT efforts. Subsequently, changes were introduced in control orders, preventive detention orders, access to airline information, and stop-search-andquestion powers at transport hubs and places of mass gatherings, along with 
changes to the Australia Security Intelligence Organisation (ASIO) warrant scheme. The strengthening of existing offences and the creation of new offences informed the Anti-Terrorism Bill (November 2005) and Anti-Money Laundering and Counter- Terrorism Financing Bill (December 2005). ${ }^{51}$ Along the lines of the United 
Kingdom's Terrorism Act 2000, Australia too separated terrorism laws from other criminal offences, while the criminal law was expanded to deal with association with terror groups and participation in a terrorist act. ${ }^{52}$

Simultaneously, the COAG also recommended that provisions be enacted to allow a periodic (five years) review of these laws to 'evaluate operation, effectiveness and implications' and ensure that CT laws are 'necessary, effective against terrorism and contain appropriate safeguards against abuse'. The review would incorporate the views and reviews of the states and territories and invite public submissions and hearings and briefings from government agencies to this effect. ${ }^{53}$ However, due to unspecified reasons, the first review only occurred in August 2012 under former prime minister Julia Gillard, and the COAG Review report was submitted in March 2013, for the government to act accordingly. ${ }^{54}$

Overall, the legislative changes introduced between 2001 and 2010 pertained to control orders, money laundering, terrorist financing, preventive detention, aviation and transport security, telecommunication (interception) and sedition. Major amend- ments were introduced by the National Security Legislation Amendment Bill 2010 which incorporated a number of recommendations made by: the Hon. John Clarke QC inquiry (2008); the review of sedition laws by the Australian Law Reform Commission (2006); the review of security and counter-terrorism legislation by the Parliamentary Joint Committee on Intelligence and Security (PJCIS) (December 2006); and the inquiry into the proscription of 'terrorist organisations' under the Criminal Code 
(2007). Significantly, the amendments included: granting increased powers to the police for search without warrants in emergency situation; limits on the detention period; establishing a Parliamentary Joint Committee on Law Enforcement to extend parliamentary oversight to both the AFP and Australian Crime Commission; and extending the role of the Inspector General of Intelligence and Security to strengthen the oversight and accountability of government agencies..$^{55}$

\section{Major Reviews}

The Robert Cornall review (October 2001) assessed the possibility of September 11- type attacks on Australian soil and recommended that the government 'consolidate and strengthen legal powers to investigate, prevent and respond to the challenges of the new type of terrorist threat', as a deterrence. ${ }^{56}$ The Philip Flood inquiry (March 2004) looked into Australia's foreign intelligence agencies, including the Office of National Assessment (ONA), the Australian Secret Intelligence Service (ASIS), the Defence Intelligence Organisation (DIO), the Defence Signals Directorate (DSD), and the Defence Imagery and Spatial Organisation (DISO), to bolster the effectiveness, oversight and accountability of these agencies; the separation of powers and their interoperability; communication and resources; and their linkages with ASIO. ${ }^{57}$ In 2005 the Allan Taylor review again examined the ASIO's technical and professional capabilities and the resources required to deal with future challenges. ${ }^{58}$ Two years later, the Lawrence Street review took stock of the 
AFP's effectiveness and opera- tional linkages with its national security partners, and recommended that prosecution be melded with the investigation process to make the CT policies more effective. ${ }^{59}$ In 2008, the Ric Smith review assessed Australia's border, homeland and national security and recommended the posting of a National Security Advisor in the Department of the Prime Minister and Cabinet and more effective emergency manage- ment and mechanisms to deal with organised crimes and cyber-attacks. ${ }^{60}$ Around this 
time, the John Clarke inquiry was launched into the Indian doctor Muhammad Haneef's case, who was charged with providing a SIM card to his cousin in London, who was involved in the London and Glasgow bombings. Haneef's passport was cancelled in Australia and he was detained for 12 days before being formally charged, but was later acquitted by the court and given due compensation. The resulting inquiry reviewed the appropriateness of the use of CT laws in the case, as well as criminal and migration laws, with a view to better safeguard community and individual rights. ${ }^{61}$ In 2015 , after a seven-year hiatus, another review of Australia's counter-terrorism machinery was undertaken at the recommendation of the National Security Committee of Cabinet in the wake of the evolving and transforming terrorism threats in Australia. It called for improved arrangements to disrupt terrorist threats; detect and undermine terrorism financing, terrorist capabilities, and ideological support; and promote community resilience and cohesion. ${ }^{62}$ In the 2015 Martin Place siege, the joint New South Wales review recommended new bail arrangements for the state, including a strict 'show cause notice' and new programmes to counter violent extremism in the community ${ }^{63}$ A separate New South Wales coroner's inquest was also ordered to look into the circumstances of the hostage deaths and the police response. It criticised the delayed police response in neutralising Monis, after one of the hostages was shot by the latter. $^{64}$ 
In the face of growing threats from 'lone actors' or 'leaderless jihadis', Tony Abbott had highlighted the rise in HGT tendencies in Australia and the need for legislative changes to counter them. The changes that transpired following his remarks focused on preventing Australians from leaving, prosecuting returning fighters and extremists upon their return, monitoring local individuals to prevent them from committing terrorist acts, and strengthening community cohesion through the Countering Violent Extremism (CVE) programme. The government also earmarked \$630 million for 2014-2018 to enable the national security agen- cies to boost their CT efforts. ${ }^{65}$

The key legislative changes under Tony Abbott consisted of the following:

(1) The National Security Legislation Amendment Bill (No. 10 2014);

(2) The Counter-Terrorism Legislation Amendment (Foreign Fighters) Bill; and

(3) The Telecommunications (Interception and Access) Amendment (Data Retention) Bill 2014.

The key features of the first bill passed by Parliament on September 25, 2014 included: training ASIO officers to disrupt operations of targeted computers; operat- ing with contractors and seconded public servants in other parts of public service; criminal and civil immunity from prosecution, for ASIO and Australian Security Intelligence Service (ASIS) officials along with reduced oversight; and a higher penalty (five years) for revealing information (such as by journalists among others) about any special intelligence operations. 
The second bill, passed on October 29, 2014, empowered the law enforcement agencies to easily identify, charge and prosecute Australians for: involvement in terrorism abroad; deem travel to a 'declared area' without a valid reason as a 'terrorist activity', except for humanitarian and family reasons, with the burden of proof resting 
with the traveller; and 'terrorism activity' which was replaced with 'terrorism' by broadening the base for such acts under law. 'Advocating terrorism' on social media was made punishable: by 5 years imprisonment; suspects' passport to be suspended for 14 days; a lowered threshold for granting control orders and preventive detention orders; stoppage of welfare payments for persons with cancelled passports; and undertaking a periodic review of these provisions. ${ }^{66}$

The third bill, passed on October 30, 2014, enabled the telecommunication companies to retain the phone and computer metadata of their customers for two years, excluding the content of the calls, emails and browsing information; provide the information and data to the government agencies for investigation; and establish a strong independent oversight mechanism under the Commonwealth Ombudsman to audit agency records and strengthen privacy protections. ${ }^{67}$

\section{Countering Violent Extremism (CVE)}

The programme was originally mooted in December 2009 to mentor vulnerable young people, introduce intercultural and interfaith education in schools, and develop online resources and training. The initiative, however, did not yield the desired results, which led to the formulation of an amended CVE in August 2014 with a modest budget of $\$ 7$ million per annum with 3 main objectives:

(1) Formulation of intervention programmes to connect with vulnerable individuals; 
(2) Promoting resilience to extremism through education and engagements activ- ities and engaging with families, communities and local institutions; and

(3) Boosting interaction in the online environment to challenge extremist narratives. ${ }^{68}$

Under the new CVE, vulnerable or at-risk individuals would be identified, assessed and referred to support services for de-radicalisation, through services such as healthcare, mentoring, employment, education and counselling. The role of families and community leaders became vital, as the first witnesses of any change in individuals. ${ }^{69}$ With the view to counter humanitarian, ideological and identitybased extremist narratives, the role of faith and community leaders is paramount in the programme wherein the involvement of the government would only be in the background. To counter the extremist propaganda, it became necessary: (a) to monitor and enhance our understanding of extremist narra- tives; (b) introduce counter-narratives and measure their impact; and (c) build capacity of partners such a multimedia support, funding and training. ${ }^{70}$

With the view to promoting community and public private partnership, the strategy also includes engaging the sporting sector to utilise sport as a vehicle of de-radicalisation. It also sought support from social media platforms such as Google, Facebook and Twitter to remove contents deemed dangerous, inflammatory and of extreme nature. ${ }^{71}$ To promote social cohesion among the multicultural communities, $\$ 545$ million was allocated to the department of social services to undertake (a) 
intelligence-led geographical prioritisation programmes to target radical hotspots, suburbs, streets and organisations, and (b) applying evaluation metrics to measure the effectiveness of CVE programmes. ${ }^{72}$

\section{Counter-terrorism Reforms Under Malcolm Turnbull}

Under the current prime minister, Malcolm Turnbull, Australia's CounterTerrorism Strategy 2015, formulated by COAG, advocates an increased partnership between the government, communities and the private sector. The strategy has five key elements, inter alia, challenging violent extremist ideologies; stopping people from becoming terrorists; shaping the global environment (through coordinated international actions with partners and through the United Nations); disrupting terrorist activities within Australia; and ensuring effective response and recovery by states and territories in cooperation with the Commonwealth, if necessary. ${ }^{73}$ A new ministry along the lines of the UK's Home Office has also been announced for overseeing internal security and bolstering coordination, communication and information-sharing between agencies. ${ }^{74}$ Turnbull also received bipartisan support from the opposition to pass a law to force information technology companies to encrypt the messages of terrorists and other operatives on social media for investigation agencies, although the compa- nies have not agreed to this request, yet. ${ }^{75}$ In another controversial policy announce- ment, Turnbull empowered the defence forces to assist the state and territory services in a terrorist situation. ${ }^{76}$

The Turnbull government remains alert to the possibility of ISIS-inspired 
attacks on soft targets and public places. The ISIS adopted innovation in its attacks - particularly those masterminded by Abu Ayyub al-Masri since 2006by using vehicle-borne improvised explosive devices (VBIEDs) which were custom built in factories around Baghdad. ${ }^{77}$ Experts had anticipated a spurt in vehicle- borne attacks in crowded places globally, as witnessed at Finsbury Park, London (UK, June 2017), London Bridge and Borough Market (UK, June 2017), Manchester Arena (UK, May 2017), Berlin Christmas market (Germany, December 2016), Bastille Day Parade, Nice (France, July 2016) and across Iraq and Syria, over the years. In July 2017, Australian law enforcement and intelli- gence agencies busted plots to blow up a plane, by using an IED, and, in another case, using an improvised chemical dispersion device to cause harm to the com- munity. As the current threat level remains 'Probable', crowded places such as sporting arenas, shopping centres, pedestrian malls and mega events remain a potential target for terrorist groups. The new terrorist methodology of violent attacks prefers high volumes and concentration of people, over the type of location, to cause maximum damage. ${ }^{78}$

In response, Australia's ‘Strategy for Protecting Crowded Places from Terrorism'

was introduced to secure crowded places and innocent lives. It contains a new national framework entitled 'Crowded Places Partnership', that has been introduced across states and territories to bolster trusted engagement between law enforcement agencies, governments, and owners and operators of these public/private places. As members of this partnership, owners and operators can 
access improved and better security information from the commonwealth law and intelligence agencies and state and territory police. The framework also provides for organising 'Crowded Place Forums' to facilitate informationsharing with owners and operators, on whom rests the primary responsibility and duty to ensure the safety and security of people and property. As a part of the strategy, governments also emphasise the need for a well- trained private security personnel, and maintaining a robust regulatory regime around employment, training and registration. ${ }^{79}$ The strategy is subject to regular review by the Australia-New Zealand Counter-Terrorism Committee (ANZCTC), the body responsible for coordinating counter-terrorism efforts across Australia and New Zealand.

\section{Criticism of the Legislative Reforms}

Australia's CT legislations have drawn their share of domestic criticism. Scholars have been very critical of the terrorism law reform since September 11, terming it 'hyper-legislation' 80 and 'dubious enforcement' for 'highly political use' ${ }^{81}$ at the cost of democratic freedoms and civil liberties. ${ }^{82}$ Some scholars have described terrorist events as an 'irritation' which governments have used for strengthening their political standing, especially during the time of elections, when individuals caught up in the media stories are made scapegoats. ${ }^{83}$ These laws, they warn, have led to human rights violations, with weak evidence to back government action. ${ }^{84}$ Others argue that 
governments are concerned with opinion polls, mass media responses and electoral interests, and craft their responses to boost their electoral appeal and support, distancing themselves from the political opposition. However, at times counter-terrorism laws receive bipartisan support, because neither the government nor the opposition is willing to risk public backlash over potential Australian deaths in a terrorist attack and undermine their electoral prospects. ${ }^{85}$ As more terrorist acts occur, experts argue that 'politics becomes complex as it responds to irritations which are reformulated as deficits in law', and leads to 'new regulations to deal with them which are in reality usual politics'. ${ }^{86}$ Australia has the Parliamentary Joint Committee on Law Enforcement, the Human Rights and Equal Opportunity Commission and the Independent National Security Legislation Monitor (INSLM) to safeguard against human rights violations and prevent unlawful acts by government agencies, but at times not only these bodies, but courts have also been seen to be unable to provide the necessary protection. ${ }^{87}$

Many critics also assert that new laws legitimise the torture of suspects under Section $35 \mathrm{~K}$ of National Security Legislation Amendment Act (No. 1) 2014 ensuring 'Immunity from liability for special intelligence conduct during special intelligence operations'. They point out ambiguities that will allow abuse, and the law is silent on punitive measures that could cause permanent psychological damage from interrogation by intelligence and police under increased powers. For instance, many of the 'special intelligence operations' need not be approved by a minister or judicial officer and the Attorney 
General need not be informed about them. The director general of ASIO can order these operations in his own capacity. ${ }^{88}$ Senator David Leyonhjelm has also strongly criticised this: 'These provisions are shameful . . A Australia is engaged in a fight against barbarism, but that does not justify becoming barbarians ourselves ... ASIO has plenty of power to do its job without trampling on our basic rights.' 89 At the same time, as Tony Abbott emphasised, given the nature of the new threat when an individual may be suspected of planning an act, there may not be sufficient time available to seek judicial or ministerial approval. These laws have also received support from commentators who observe that the ASIO agents spend their time identifying threats against their fellow Australians and torture has never been part of the Australian intelligence culture, and ASIO 'deserves more than gratuitous insults' ${ }^{90}$ An editorial in The Australian commented that these measures are what a difficult situation requires:

No government should be given a free licence, especially when freedoms are being curbed. Yet given the current threats and tactics, the mandatory retention of metadata also seems reasonable. Media organisations and other groups must remain vigilant for any future evidence that such powers are being abused. ${ }^{91}$

But the critics of these invasive laws have continued to raise alarm about the potential erosion of individual privacy. A Sydney Morning Herald editorial described the Telecommunications (Interception and Access) Amendment (Data Retention) Bill 2014 as 'murky', as it would allow companies to retain the 
metadata for people's phones and computers. The editorial said that 'the onus is on the government' to justify the need for it, and pointed out that there is still no clear strategy to deal with HGT and no safeguards constituted to ensure that these powers would not be used other than for terrorist investigations. Therefore, while the rationale for tougher anti-terrorism laws may be there in the face of evolving threat, the need for metadata retention was questionable. ${ }^{92}$ Similarly, with regard to Section 35P, 'Unauthorised disclosure of information' of the National Security Legislation Amendment Act (No. 1) 2014, critics suggest that it would criminalise the media for doing an Edward Snowden-style exposé. ${ }^{93}$ There is a fear that Australian journalists could face prosecution and jail for revealing information about 'special intelligence operations'. However the Attorney General has dismissed such apprehensions, saying that it is aimed at plugging the existing gap in law (which does not cover deleting and copying of data wrongfully) and thereby preventing intelligence officials from passing on the information. ${ }^{94}$ Some barristers also agree that Section $35 \mathrm{P}$ "would capture the likes of Wikileaks, the Guardian, The New York Times, and any other media organisation that reports on such materials', and such clauses 'you don't expect to see in a democracy'. ${ }^{95}$ Senator Scott Ludlam has called it 'quite draconian' and sees no safeguards for journalists. Electronics Frontiers Australia Chief Jon Lawrence says these laws would clamp down on Ed Snowden-type whistleblowers. ${ }^{96}$ Others are of the opinion that Section $35 \mathrm{P}$ is too broad and it would prevent the reporting of an innocent person being killed in a botched-up operation. Therefore, it must be amended to include only civil servants and not 'everyone' 
else. ${ }^{97}$ Some leading journalists are also uncom- fortable with the potential curbs on the media. Greg Sheridan writes that 'the revelation of the records of interview [in Muhammad Haneef's case] showed glaring gaps in the knowledge and practice of the agencies .. [it allows the public] access to more information than would otherwise be the case ... US foreign policy is facing difficulty' due to 'the decline of authoritative media institutions and individuals who can interpret, and to some extent adjudicate, national security matters to the public. [It] will gravely

weaken the position of responsible journalists who work on national security. ${ }^{98}$

In the Muhammad Haneef case, the courts had granted him bail and ordered due compensation from the government for unlawful detention. Muhammad Haneef was arrested and detained without any charge for allegedly providing a SIM card to his cousin, involved in the London and Glasgow bombings in 2007. Later the law enforcement agencies also acknowledged that there were 'insufficient grounds' to arrest and detain Haneef, and following investigations the Federal Court cleared him of all charges. ${ }^{99}$

\section{Conclusion}

Australia has been a victim of terrorism, although most casualties have occurred overseas, in tourist places and conflict zones. But now the threat has reached Australian shores. Since 2004, Australia has witnessed increasing numbers of HGT plots and attacks from lone actors or self-radicalised individuals, a trend also wit- nessed in the US and Europe. Successive Australian governments have 
acknowledged the growing dangers to the community. The COAG, the Attorney General's depart- ment and the state and territory governments have reviewed CT laws and introduced the changes necessary for an effective CT strategy. Passing new laws to prevent Australians from joining the ISIS and other groups; prosecuting them upon their return; preventing attacks within Australia by providing greater powers to intelligence and police agencies for investigation, arrests and crackdowns; and strengthening community cohesion against radicalisation, through the CVE programme, indicate a comprehensive preventive and enforcement $\mathrm{CT}$ response. But the new laws have been challenged by the critics, given their intrusive and incursive mandate. Laws such as control orders, preventive detention orders and greater access to meta data granting more intrusive powers to the law enforcement and intelligence agencies have been labelled as politically motivated by critics, warning against a potential abuse of powers, as witnessed in the Muhammad Haneef case. Some have described the government response as 'hyper-legislation' which may erode civil liberties and free- dom of the press.

A large section of the media has expressed serious reservations about Section 35P

of the National Security Legislation Amendment Bill (No. 10 2014), fearing it would imprison journalists for two years for reporting on 'special intelligence operations'. It has been argued that the Section would curtail the safeguards designed to protect the journalists' right to report on matters impacting community interests, under the garb of national security and bureaucratic 
secrecy. In particular, laws providing for meta- data retention are being seen as detrimental to individual privacy.

However, it would be prudent to first give these legislations some time to operate, before their effectiveness and implications can be determined more meaningfully and effectively. It is noteworthy that the COAG has recommended a periodic review of the legislations and law enforcement responses, which would be buttressed by the robust oversight of the Parliamentary Joint Committee on Law Enforcement, Human Rights and Equal Opportunity Commission and INSLM. The advent of HGT, quite justifi- ably, necessitated the CT law reforms to deal with the rapidly evolving nature of terrorism on home soil. Since 2001, the eight reviews of the national security apparatus, and the evolving nature of terrorist threats, have demonstrated Australia's sustained focus on terrorism and also on safeguarding individual liberties. The 2010 INLSM Act, amended in 2014, is a clear example of how past CT experiences influence current national security policies and legislations. To prevent another Muhammad Haneef-type controversy, wherein the accused was arrested and detained without 'sufficient evidence', the INLSM mandates a regular review of CT operations, their effectiveness, and the implications of the national security legislations for both national security and the rights of individuals. In sum, Australia's national security and CT legislations have evolved through a rigorous review and monitoring process, and the establishment of an independent oversight mechanism to monitor the CT responses is further evidence of the resolve to harmonise the imperatives of national security and 
individual liberties.

\section{Disclosure statement}

No potential conflict of interest was reported by the authors

\section{Notes}

1. 'Fact File: Five Facts about Terrorism in Australia', $A B C$ News, February 25, 2015.

2. Mark Finnane, 'The Munich Olympics Massacre and the Development of CounterTerrorism in Australia', Intelligence and National Security, 20(6), 2015, p. 820.

3. The group was founded in 1955 in India by Anandamurti as the 'Path of Bliss' to help human beings realise full potential and attain spiritual perfection, at http://anandamarga.org.au/about- us/ (Accessed December 2, 2017).

4. 'Attaché Kidnap Case: Man on Remand', Sydney Morning Herald, September 20, 1977.

5. 'Fact File', no.1.

6. Four offences were inserted into Division 104 of the Criminal Code Act 1995 (Commonwealth, Cth): murder of an Australian citizen or a resident of Australia (s 104.1); manslaughter of an Australian citizen or a resident of Australia (s 104.2); intentionally causing serious harm to an Australian citizen or a resident of Australia (s 104.3); and recklessly causing serious harm to an Australian citizen or a resident of Australia (s 104.4). The offences attract the following maximum penalties: murder, life imprisonment; manslaughter, 25 years imprisonment; intentionally causing serious harm, 20 years impri- sonment; and recklessly causing serious harm, 15 years imprisonment.

7. Australian Government, 'Battle Casualties in Afghanistan', Department of Defence, 2013, at http://www.defence.gov.au/operations/afghanistan/personnel.asp (Accessed March 22,2014).

8. Australian Government, 'Counter-Terrorism White Paper 2010', Department of Defence, 2011, at http://www.dsto.defence.gov.au/national-security/page/6905/ (Accessed March 22, 2013).

9. Samantha Maiden, 'Authorities Cancel Passport of Three Men Suspected of Going to Fight for Terrorist Groups Overseas', Daily Telegraph, September 28, 2014.

10. Bonnie Malkin, 'Australian Muslims Found Guilty of Terror Plots', The Telegraph, December 23, 2010.

11. According to the 2011 Australian Census, 2.2 per cent $(476,290)$ of the population $(21.5$ million) were Muslims, of whom 41.9 per cent of Muslims in terms of geography as the proxy for ethnicity/ ancestry were of North African and Middle Eastern Origin; and 25 per cent were of South Asian and Central Asian origin. In Australia, 46.1 per cent of Muslims live in New South Wales constituting 3.2 per cent of the total population, 32.1 per cent in Victoria constituting 2.1 per cent of the total population, and 7.1 per cent in Queensland constituting 3.2 per cent of the total population 0.8 per cent of the total population. New South Wales, Victoria and Queensland are the three states where most of the counter-terrorism raids have occurred and terrorist plots been busted. For further details, see 'Australian Muslims: A Demographic, Social and Economic Profile of Muslims in Australia,' University of South Australia, 2015, at https://www.unisa.edu.au/Global/

EASS/MnM/Publications/Australian_Muslims_Report_2015.pdf (Accessed November 
24, 2017).

12. 'Terrorist Raids: Pendennis Nine and Other Major Anti-Terrorist Operations', The Sydney Morning Herald, September 18, 2014.

13. Jeffrey Kaplan, 'Leaderless Resistance', Terrorism and Political Violence, 9(3), 1997, p. 80, in George Michael, 'Counterinsurgency and Lone Wolf Terrorism', Terrorism and Political Violence, 26(45-57), 2014, p. 46. Also see Marc Sageman, Leaderless Jihad: Terror Networks in the Twenty-First Century, University of Pennsylvania Press, Philadelphia, 2008, p. 125.

14. George Michael, no. 13, p. 48. The author describes the Napoleonic Wars (fought by sheer huge armies) as first-generation warfare; World War I with new technology and tactics and trench warfare as second-generation warfare; World War II with improved military power and communication as third-generation warfare; and Mao Zedong's peasant-based guerrillatactics as fourth-generation warfare, p. 46.

15. Marc Sageman, no. 13, pp. 49, 133-146.

16. Prime Minister of Australia, The Hon. Tony Abbott, MP, 'National Security Statement, Canberra', February 23, 2015, at http://www.pm.gov.au/media/2015-02-23/nationalsecurity- statement-canberra (Accessed February 25, 2015).

17. Ibid.

18. Ibid.

19. Ibid.

20. Australian Government, 'Review of Australia's Counter-Terrorism Machinery', Department of Prime Minister and Cabinet, January 2015, at http://www.dpmc.gov.au/sites/default/files/pub lications/190215_CT_Review_0.pdf (Accessed March 23, 2015).

21. 'Anti-Terror Operation in Sydney and Brisbane "Thwarted" Beheading Plot', $A B C$ News, September 18, 2014, at http://www.abc.net.au/news/2014-09-18/anti-terrorpolice-mount- large-scale-raids-in-sydney-brisbane 15752002 (Accessed October 3, 2014).

22. 'Terrorist Raids', no. 12.

23. Cameron Stewart, 'Driven to Kill by Islamic State', The Australian, September 25, 2014.

24. Australian Government, 'Martin Place Seize: Joint Commonwealth-New South Wales Review', Department of the Prime Minister and Cabinet, New South Wales Government and Premier and Cabinet, January 2015, at http://www.nsw.gov.au/sites/default/files/170215__ martin_place_siege_review_1.pdf (Accessed March 23, 2015).

25. Mark Schliebs, 'Agencies Fail to Stem Jihad flow', The Australian, November 5, 2014.

26. Ibid.

27. Paul Maley, 'Aussie Jihadis "Cannon Fodder" ', The Australian, December 9, 2015.

28. Mark Schliebs, 'Sydney Teen's Jihad Challenge to the West', The Australian, October $22,2014$.

29. Joe Kelly, 'Teenage Brothers Stopped at Sydney Airport "Kids not Killers" ', The Australian, March 8, 2015.

30. Jared Owens, 'Julie Bishop Warns Young Women Against Becoming "Jihadi Brides" ', The Australian, February 25, 2015. Also see Susan McDonald, 'Islamic State: Up to 40 Australian Women, Indulging "Jihadi Brides", Supporting Terrorist Activity in Syria and Iraq, Julie Bishop says', $A B C$ News, February 26, 2015, at http://www.abc.net.au/news/2015-02-25/40- australian-women-supported-terroristsiraq-syria-bishop-says/6262452 (Accessed March 22, 2015).

31. Jared Owens, no. 29.

32. Australian Government, 'Review of Australia's Counter-Terrorism Machinery', no. 20, p. 35 .

33. Australian Government, 'Terrorism Financing in Australia 2014', Australian Transaction Reports and Analysis http://www.austrac.gov.au/sites/default/files/docu Centre, 2014, at ments/terrorism-financing-in- 
australia-2014.pdf (Accessed March 12, 2015).

34. All figures in the article are in Australian dollars.

35. Nick Ralston, Emma Patridge, David Wroe, 'Sharrouf Family Form Shut Over Terror Funding Fears', Sydney Morning Herald, September 17, 2014.

36. Michael Safi, 'Two Men Charged with Funding Travel of Australians Fighting with ISIS', The Guardian, December 15, 2014.

37. John Ferguson, Rachel Baxendale, Pia Akerman, 'Terror Fight Turns Up Heat on Funders of Jihad', The Australian, October 1,2014.

38. Australian Government, Criminal Code Act 1995, p. 137, at http://www.comlaw.gov.au/ Details/C2014C00793 (Accessed July 3, 2014).

39. Ibid., p. 146.

40. Ibid., p. 147.

41. Ibid., p. 156

42. Ibid., p. 157

43. Ibid.

44. Ibid.

45. Ibid, $\mathrm{p}$

160. 46 .

Ibid., p. 164.

47. Ibid., pp. 166-176.

48. Ibid., pp. 196-251.

49. Ibid., p. 9.

50. Australian Government, 'Council of Australian Governments Review of CounterTerrorism Legislation', Council of Australian Governments, 2013, at http://www.ag.gov.au/

Consultations/Documents/COAGCTReview/Final\%20Report.PDF (Accessed July 3, 2014).

51. Ibid.

52. Kent Roach, The 9/11 Effect Comparative Counter-Terrorism, Cambridge University Press, Cambridge, 2011, pp. 74-75.

53. Ibid.

54. Ibid.

55. Australian Government, 'National Security Legislation Amendment Act 2010-No. 127, 2010: An Act to Amend the Law Relating to Terrorism and National Security, and for Other Purposes', at file:///C:/Users/s2639762/Downloads/C2010A00127.pdf

56. The Hon. Daryl Williams, AM QC MP, 'Upgrading Australia's Counter-Terrorism Capabilities', Media Release, December 18, 2001.

57. Philip Flood, AO, 'Report of the Inquiry into Australian Intelligence Agencies', Australian Government, July 2004, p. 1, at http://fas.org/irp/world/australia/flood.pdf (Accessed September 3, 2017).

58. Australia Security Intelligence Organisation, 'Parliamentary Joint Committee on Intelligence and Security Review of Administration and Expenditure No. 4: Recruitment and Training Submission', February 2, 2006, at http://www.asio.gov.au/img/files/Review-of- Administration-andExpenditure.pdf (Accessed July 3, 2014).

59. The Honourable Sir Lawrence Street, AC, KCMG, QC, 'The Street Review: A Review of Interoperability Between the AFP and its National Security Partners', 2007, at http://www.afp. gov.au/ /media/afp/pdf/t/the-street-review.pdf (Accessed July 3, 2014).

60. Ric Smith, 'Summary and Conclusions-Report of Homeland and Border Security', December 4, 2008, at http://www.royalcommission.vic.gov.au/getdoc/0be3af5e-16eb4ba5- 93c0-b83cb3a55860/TEN.004. 002.0431.pdf (Accessed July 3, 2014).

61. The Hon. Mr. Clarke, QC, 'Clarke Inquiry into the Case of Dr Mohamed Haneef', Law Council of Australia, May 16, 2008, at http://www.lawcouncil.asn.au/lawcouncil/images/ LCA-PDF/a-z-docs/LawCouncil 
SubmissiontoHaneefInquiry-Final.pdf.as (Accessed July 3, 2014).

62. Australian Government, 'Review of Australia's Counter-Terrorism Machinery', Department of Prime Minister and Cabinet, January 2015, at http://www.dpmc.gov.au/sites/default/files/pub lications/190215_CT_Review_0.pdf (Accessed June 13, 2015).

63 Australian Government, 'Martin Place seize: Joint Commonwealth-New South Wales Review', Department of the Prime Minister and Cabinet, New South Wales Government and Premier and Cabinet, January 2015, at http://www.nsw.gov.au/sites/default/files/170215_ martin_place_siege_review_1.pdf (Accessed November 8, 2015).

64. State Coroner New South Wales, 'Inquest in the Deaths Arising From the Lindt Café Siege: Findings and Recommendations', New South Wales Government, May 2017, at http://www. lindtinquest.justice.nsw.gov.au/ Documents/findings-andrecommendations.pdf (Accessed September 13, 2017).

65. Latika Bourke, and James Massola, 'Tony Abbott Boosts Funding by $\$ 630 \mathrm{~m}$ to Fight Home- Grown Terrorism', Sydney Morning Herald, August 6, 2014.

66. Ibid. For further details of the bill, see the Parliament of the Government of Australia, 'Counter-Terrorism Legislation Amendment (Foreign Fighters) Act 2014 No. 116, 2014- An Act to Amend the Law Relating to National Security and Intelligence Services, and for Related Purposes', 2013-2014, at http://www.comlaw.gov.au /Details/C2014A00116/ Download (Accessed March 22, 2015).

67. Ibid. For details of the bill, see The Parliament of the Government of Australia, 'Telecommunications (Interception and Access) Amendment (Data Retention) Bill 2014 (Attorney-General)-A Bill for an Act to Amend the Telecommunications (Interception and Access) Act 1979, and for Related Purposes', 2013-2014, House of Representatives, at http:// www.comlaw.gov.au/Details/C2014B00230 /Download (Accessed March 22, 2015).

68. Australian Government, 'Review of Australia's Counter-Terrorism Machinery', no. 20, pp. 30-35.

69. Ibid.

70. Ibid.

71. Ibid., p. 33.

72. Ibid., p. 34.

73. Council of Australian Governments, 'Australia's Counter-Terrorism Strategy: Strengthening Our Resilience 2015', Commonwealth of Australia, 2015, at https://www.nationalsecurity.gov. $\quad$ au/Media-andpublications/Publications/Documents/Australias-Counter-Terrorism-Strategy- 2015.pdf (Accessed September 2, 2017).

74. Sharri Markson, 'Home Affairs will Tackle Terror Under Malcolm Turnbull's Plan', The Telegraph, July 18, 2017.

75. Rachel Baxendale, 'Laws could Force Companies to Unlock Encrypted Messages of Terrorists', The Australian, July 14, 2017.

76. Louise Yaxley, 'Terrorism: Prime Minister Turnbull Gives Defence Forces Power to Help Police During Attacks', $A B C$, July 17, 2017.

77. Michael Weiss, and Hassan Hassan, ISIS: Inside Army of Terror, Regan Arts, New York, 2016, p. 68.

78. Commonwealth of Australia, 'Australia's Strategy for Protecting Crowded Places from Terrorism', Australia-New Zealand Counter-Terrorism Committee', at https://www.nationalse curity.gov.au/Media-andpublications/Publications/Documents/crowded-places-security-audit. pdf (Accessed August 14, 2017).

79. Ibid.

80. Kent Roach, no. 52, p. 310.

81. Michael Head, Crime Against the State: From Treason to Terrorism, Ashgate, Burlington, VT, 2011, p. 220. 
82. George Williams, 'A Decade of Australian Anti-terror Laws', Melbourne University Law Review, 35, 2011, p. 1171.

83. Ann-Claire Larsen, Michael Crowley, 'Government as Usual: Politics and Law as Structural Couples Governing Counter-terrorism in Australia', Griffith Law Review, 24(4), 2015, pp. 522-523.

84. Niklas Luhmann, Law as a Social System, Oxford University Press, Oxford, 2004, p. 402.

85. Ann-Claire Larsen, Michael Crowley, no. 83,

p. 528. 86. Ibid., p. 533.

87. Ibid., p. 538.

88. Paul Sheehan, 'George Brandis' New Anti-Terror Law Allows ASIO to Torture', Sydney Morning Herald, September 18, 2014.

89. Ibid.

90. Cameron Stewart, 'Senator David Leyonhjelm's Reasoning Tortured', The Australian, September 23, 2014.

91. Editorial, 'Terror Laws Protect Unity Rather than Undermine', The Australian, September 23, 2014.

92. Editorial, 'Home-Grown Terror Response Risks Government Overreach', Sydney Morning Herald, August 12, 2014.

93. Paul Farrell, Daniel Hurst, 'Journalist will Face Jail Over Spy Leaks Under New Security Laws', The Guardian, July 16, 2014.

94. George Brandis, 'ASIO Powers are No Threat to Journalists', The Australian, October 14, 2014.

95. Paul Farrell, Daniel Hurst, no. 93.

96. Ibid.

97. Tim Wilson, 'Tackle Two Free-Speech Obstacles at Once', The Australian, November 7, 2014.

98. Greg Sheridan, 'Proposed Media Curbs are Not Just Wrong in Principle, They are Dumb', The Australian, November 6, 2014.

99. Selma Milovanovic, 'Haneef Case: Timeline of Events', The Sydney Morning Herald, December 23, 2008. 